\title{
THE EFFECT OF FREEZING-THAWING AND MARINATION TIME ON COOKED CHICKEN BREAST MEAT QUALITY
}

\author{
Maja Ivić1 ${ }^{*}$, Marija Jokanović ${ }^{1}$, Natalija Džinić1, Vladimir Tomović ${ }^{1}$, \\ Snežana Škaljac ${ }^{1}$, Branislav Šojić ${ }^{1}$, Tatjana Peulić́ ${ }^{2}$, Predrag Ikonić \\ ${ }^{1}$ University of Novi Sad, Faculty of Technology Novi Sad \\ ${ }^{2}$ University of Novi Sad, Institute of Food Technology in Novi Sad
}

\section{Abstract}

Marination is often used to improve the yield and quality of chicken breast fillets. The effects of freezing-thawing prior to marination and marination holding time on the instrumental and sensory properties of cooked marinated chicken fillets were investigated. Fillets were marinated fresh or stored at $-18{ }^{\circ} \mathrm{C}$ and then thawed prior to marination (frozen-thawed). Fillets were soaked in marinade for $1.5 \mathrm{~h}$ and $20 \mathrm{~h}$ and then cooked at $175^{\circ} \mathrm{C}$ for 45 minutes for determination of cooking loss, Warner-Bratzler shear force, color properties, juiciness and sensory properties. Marinade uptake was greater in fillets marinated for $20 \mathrm{~h}$, both fresh and frozen-thawed, than in fillets marinated for $1.5 \mathrm{~h}$. Cooking loss was lowest for fresh unmarinated fillets $(19.30 \%)$ and significantly lower $(P<0.05)$ comparing to frozenthawed fillets marinated for $20 \mathrm{~h}(44.73 \%)$. The highest numerical value of color parameter lightness was found in fresh fillet marinated for $1.5 \mathrm{~h}$. There were no significant differences between all examined fillets regarding color properties redness and yellowness. The fillets marinated for $20 \mathrm{~h}$, both fresh and frozen-thawed were found to be significantly more tender $(P<0.05)$ as indicated by lower shear force values (13.96 N and $12.88 \mathrm{~N}$, respectively) and higher sensory scores for tenderness (7.00 and 6.50, respectively) as compared to other investigated fillets. Furthermore, fresh fillets marinated for $20 \mathrm{~h}$ had the highest mark for the overall sensory acceptability $(95.00 \%$ of maximum quality).

Keywords: chicken fillets, marinating, texture, sensory quality

\footnotetext{
${ }^{1 *}$ Corresponding author: ramajana1988@gmail.com
} 


\section{UTICAJ SMRZAVANJA-ODMRZAVANJA I VREMENA MARINIRANJA NA KVALITET TERMIČKI OBRAĐENOG PILEĆEG MESA}

Maja Ivićc ${ }^{1 *}$, Marija Jokanović1 ${ }^{1}$ Natalija Džinić ${ }^{1}$, Vladimir Tomović ${ }^{1}$, Snežana Škaljac ${ }^{1}$, Branislav Šojić ${ }^{1}$, Tatjana Peulić2 ${ }^{2}$ Predrag Ikonić ${ }^{2}$

${ }^{1}$ Univerzitet Novi Sad, Tehnološki fakultet, Novi Sad, Srbija

${ }^{2}$ Univerzitet Novi Sad, Naučni institut za prehrambene tehnologije, Novi Sad, Srbija

\section{Kratak sadržaj}

Mariniranje se često koristi kako bi se povećao prinos i poboljšao ukupni kvalitet pilećeg mesa. U ovom radu je ispitivan uticaj smrzavanjaodmrzavanja pre mariniranja i vremena mariniranja na instrumentalna i senzorska svojstva termički obrađenih pilećih filea. Filei su marinirani sveži ili nakon odmrzavanja (skladišteni na $-18^{\circ} \mathrm{C}$ ). Filei su bili potopljeni u marinadu u trajanju od 1,5 čas, odnosno 20 časova i termički obrađeni na $175^{\circ} \mathrm{C}$ u trajanju od 45 minuta, radi određivanja kala termičke obrade, Warner-Bratzler sile presecanja, instrumentalnih parametara boje, sočnosti i senzorskih svojstava. U obe grupe uzoraka prinos mariniranjem je bio veći nakon 20 časova u poređenju sa fileima mariniranim 1,5 čas. Kalo termičke obrade je bio najmanji u svežim nemariniranim fileima (19.30\%) i značajno niže vrednosti $(P<0,05)$ u poređenju sa odmrznutim fileima mariniranim u trajanju od 20 časova (44.73\%). Najveća izmerena vrednost za svetloću zabeležena je u svežim fileima mariniranim 1,5 čas. Nije uočena značajna razlika među ispitivanim uzorcima filea što se tiče parametara udela crvene boje i udela žute boje. Obe grupe uzoraka, marinirane 20 časova, bile su značajno nežnije $(P<0.05)$ što su pokazale manje vrednosti sile presecanja (13,96 N i 12,88 N, respektivno) i veće vrednosti senzorskog svojstva nežnosti (7,00 i 6,50, respektivno) u poređenju sa ostalim ispitivanim fileima. Dalje, sveži filei marinirani 20 časova imali su najveću ocenu ukupne senzorske prihvatljivosti (95,00\% maksimalnog senzorskog kvaliteta).

Ključne reči: pileći fileti, mariniranje, teksture, senzorski kvalitet

\section{INTRODUCTION}

Marination is the process of applying a water-based solution composed of ingredients such as salt, sugar, oil, organic acids, herbs and food additives such 
as aroma enhancers, antioxidants and antimicrobials (Björkroth, 2005; Haute et al., 2016). Marinades are incorporated into meat by soaking, massaging, tumbling, or injecting (Parks et al., 2000). Originally, marinating was used to preserve the meat product over a longer time. Today, marinating is adopted by restaurants and industry in order to change the flavor profile of products, improve meat tenderness and juiciness, as well as to enhance yield by increasing retention and water content (Mielnik et al., 2008; Bianci et al., 2009) and is especially used for poultry products (Barbanti et al., 2005). Market forms of marinated poultry include whole birds, cut-up parts, boneless meat, and chopped and formed items. Many products sold in the raw, unmarinated state will be marinated by the retailer or by the consumer in the home prior to sale or consumption, respectively (Smith and Acton, 2010).

The functionality of marinades is dependent on the ingredients in aqueous solution. The most common ingredients in commercial marinades are $\mathrm{NaCl}$, some type of phosphate and herbs and spices. Sodium chloride is a natural flavor enhancer that improves the taste and aroma of meat products. The addition of sodium chloride promotes uptake of water due to the electrostatic repulsion and partially solubilization of proteins (Bianci et al., 2009; Alvarado and McKee, 2007). Herbs and spices are usually added to provide a variety of flavors and aromas to marinades and to offset (harmonize) the bland chicken meat taste (Parks et al., 2000).

Some previous studies have investigated the influence of processing variables such as marinade ingredients and concentration, marination duration (the time course for marinade absorption), temperature, and chicken breast meat freezing-thawing on final product quality attributes (Heath and Owens, 1991; Xiong and Kupski, 1999; Bowker and Zhuang, 2017; Fenton et al.; Zheng et al., 2000). The formation of ice crystals during meat freezing can disrupt muscle cells and cause the loss of product structure that does not recover when thawed (Kaale and Eikevik, 2014; Leygonie et al., 2012).

The objective of this study was to determine the effects of fresh neverfrozen chicken breast meat and breast meat that was frozen and thawed prior to marination and marination holding time on final product quality attributes.

\section{MATERIAL AND METHODS}

\section{Raw materials}

The chicken carcasses used in the present study were obtained from a local processing plant. Chilled chicken carcasses $(n=40)$ were cut to the basic anatomical parts. Fresh breast meat was divided into two halves, one half was im- 
mediately marinated, and the other half was frozen and stored for 10 days, and marinated after defrosting. Chicken breast meat samples were distributed into 6 groups and the marinating processes were performed as shown in Table 1.

Table 1. Control and experimental groups of fillets

\begin{tabular}{|l|l|}
\hline $\mathrm{K}_{\mathrm{F}}-$ Control group & Fresh chicken breast meat \\
\hline $\mathrm{F}_{1}-$ Experimental group & $\begin{array}{l}\text { Fresh chicken breast meat } \\
\text { marinated for } 1.5 \mathrm{~h}\end{array}$ \\
\hline $\mathrm{F}_{2}-$ Experimental group & Fresh chicken breast meat marinated for $20 \mathrm{~h}$ \\
\hline $\mathrm{K}_{\mathrm{D}}$ - Control group & Defrosted chicken breast meat \\
\hline $\mathrm{D}_{1}-$ Experimental group & $\begin{array}{l}\text { Defrosted chicken breast meat } \\
\text { marinated for } 1.5 \mathrm{~h}\end{array}$ \\
\hline $\mathrm{D}_{2}-$ Experimental group & $\begin{array}{l}\text { Defrosted chicken breast meat } \\
\text { marinated for } 20 \mathrm{~h}\end{array}$ \\
\hline
\end{tabular}

\section{Marinating process}

Weighed and individually identified fresh and defrosted fillets were soaked in marinade in proportion of $1.25 \mathrm{~kg}$ marinade per $1.00 \mathrm{~kg}$ meat. The marinade consisted of salt $(2.08 \%)$, sugar $(4.00 \%)$, cinnamon powder $(0.03 \%)$, dried thyme $(0.03 \%)$, ginger powder $(0.03 \%)$, mustard seed $(0.17 \%)$ and pepper $(0.17 \%)$. The content of spices is expressed in $\%$ in relation to water. The fillets were marinated at $2{ }^{\circ} \mathrm{C}$ for $1.5 \mathrm{~h} \mathrm{(F1} \mathrm{and} \mathrm{D1)} \mathrm{and} \mathrm{for} 20 \mathrm{~h}$ (F2 and D2) by soaking in plastic boxes. Chicken fillets from control groups were cooked without prior marination.

\section{Marinade uptake}

The samples weight was recorded before and after marinating. After the preset marinating time, the parts were removed from the marinade and drained for 10 min before determining the marinade retention. Calculation for marinade uptake was as follows: marinade uptake $(\%)=$ (marinated weight - raw weight) / raw weight $\mathrm{x} 100$

\section{Cooking procedure}

Before cooking, the samples were individually weighed, enwrapped in aluminum foil and introduced in the convection air oven when temperature 
reached the preset value. The cooking temperature was set at $175{ }^{\circ} \mathrm{C}$ for 45 min. After cooking, samples were cooled at room temperature for $1 \mathrm{~h}$ and then analyzed for cooking loss, color, texture and sensory characteristics. The calculation of cooking loss was as follows: cooking loss $(\%)=$ (marinated weight - cooked weight) / marinated weight x100

\section{Color determination}

The color was determined instrumentally, on the fresh cut of cooked and cooled fillet, with Minolta Chroma Meter CR-400. Color characteristics were expressed by $C I E L^{*} a^{*} b^{\star}$ system (lightness- $L^{*}$, redness and greenness - $a^{*}$; yellowness and blueness $-b^{*}$ ). Color measurements were made in duplicate.

\section{Mechanical texture analysis}

Shear force evaluation was conducted on cylinder samples taken from the center of each fillet, longitudinal to the muscle fibers. The cylinders were 1.27 $\mathrm{cm}$ in diameter. A Warner-Bratzler blade, using testing machine Texture Analyser TA XP (Stable Micro System, Godalming, England), was used to shear the samples across to the muscle fibers. Six measurements were performed on each sample to obtain mean values. A cross speed of $5 \mathrm{~mm} / \mathrm{s}$ was applied using the $5 \mathrm{~kg}$ load cell. Mean values were expressed as shear force $(\mathrm{N})$.

\section{Juiciness}

Juiciness was measured using the method of Gujral et al. (2002) with slight modifications. A meat sample $(0.5 \mathrm{~g})$ was taken from the center of the cooked and cold fillet and placed between a pair of pre-weighed filter paper and between two plexiglass plates and pressed for $1 \mathrm{~min}$ (maximally connected and tightened screws). The filter paper was weighed after pressing and the percentage of extracted juice was determined as follows: Juiciness (\%) $=($ weight of filter paper after pressing - weight of filter paper before pressing/weight of sample) x 100

\section{Sensory analysis}

A panel consisting of nine trained members of different ages performed sensory evaluation. Evaluations were performed according to a 7-point scale descriptive system, from 1 to 7 . Each mark was ascribed a distinctive quality 
level, as presented in Table 2 . The overall sensory quality was evaluated as total sum of mean scores for the sensory attributes.

Table 2. Sensory analysis of cooked chicken fillets

\begin{tabular}{|c|c|c|c|c|}
\hline \multirow{2}{*}{ Value } & \multicolumn{4}{|c|}{ Sensory attributes } \\
\cline { 2 - 5 } & Odor & Taste & Juiciness & Tenderness \\
\hline 1 & Extremely bad & Extremely bad & Extremely bad & Extremely bad \\
\hline 2 & Very bad & Very bad & Very bad & Very bad \\
\hline 3 & Bad & Bad & Bad & Bad \\
\hline 4 & $\begin{array}{c}\text { Neither good } \\
\text { nor bad }\end{array}$ & $\begin{array}{c}\text { Neither good } \\
\text { nor bad }\end{array}$ & $\begin{array}{c}\text { Neither good } \\
\text { nor bad }\end{array}$ & $\begin{array}{c}\text { Neither good } \\
\text { nor bad }\end{array}$ \\
\hline 5 & Good & Good & Good & Good \\
\hline 6 & Very good & Very good & Very good & Very good \\
\hline 7 & $\begin{array}{c}\text { Extremely } \\
\text { good }\end{array}$ & $\begin{array}{c}\text { Extremely } \\
\text { good }\end{array}$ & $\begin{array}{c}\text { Extremely } \\
\text { good }\end{array}$ & $\begin{array}{c}\text { Extremely } \\
\text { good }\end{array}$ \\
\hline
\end{tabular}

\section{Statistical analysis}

The effects of sample type (fresh or frozen-thawed) and marination time on the variables studied were analyzed by Factorial ANOVA (Statistica 13.2 Dell Inc., 2016). The Duncan's post hoc test was performed for comparison of mean values. Differences were considered significant at $P<0.05$.

\section{RESULTS AND DISCUSSION}

Increasing the marination time significantly $(P<0.05)$ increased the amount of marinade uptake by the chicken breast fillets, in both fresh and frozen-thawed fillets (Figures 1 and 2). Marinade uptake of frozen-thawed fillets was numerically lower in comparison with fresh fillets $(14.27 \%$ and $16.50 \%$, respectively) for longer marination time $(20 \mathrm{~h})$. Bowker and Zhuang (2017) found similar results for marinade absorption of fresh and frozen-thawed fillets vacuum-tumbled for 45 minutes. Chan et al. (2011) had shown that freezing significantly affected biochemical and functional properties of proteins in turkey breast meat, thus altering the functionality attributes of raw poultry meat. 

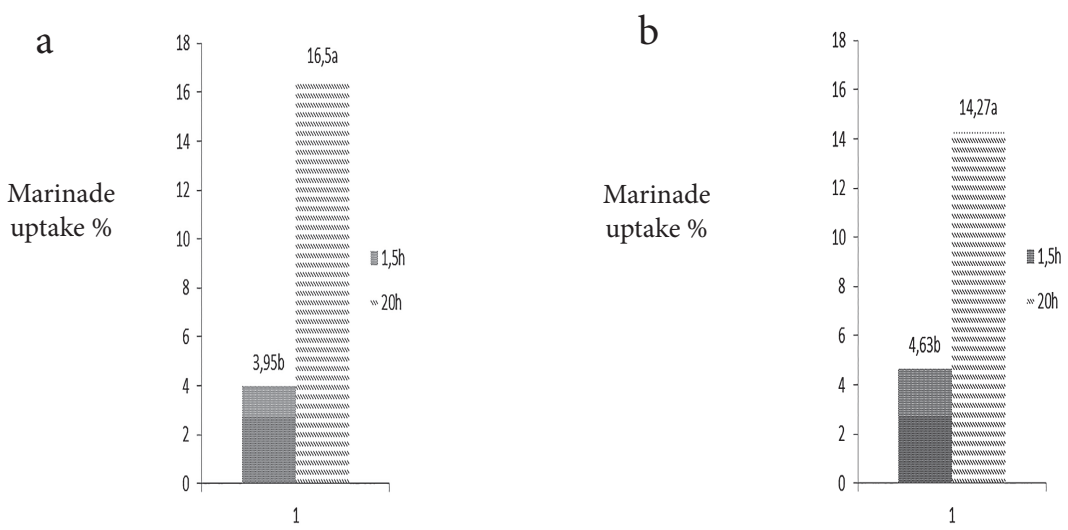

Figure 1. Marinade uptake (\%) of fresh breast fillets (a) and frozen-thawed breast fillets (b)

Significant effect $(P<0.05)$ on cooking loss was observed for sample type (fresh or frozen-thawed fillets), marination time and interaction effect (sample type $\mathrm{x}$ marination time) (Table 3). Frozen-thawed fillets marinated for $20 \mathrm{~h}$ $(44.73 \%)$ had the highest numerically cooking value.

Instrumental color parameters are presented in Table 3. Fresh chicken breast fillets unmarinated and marinated for $1.5 \mathrm{~h}$ differ significantly $(P<0.05)$ in comparison with frozen-thawed fillets unmarinated and marinated for 1.5 $\mathrm{h}$, with respect to lightness values (CIE $L^{*}$ ). However, no significant difference was observed regarding fresh and frozen-thawed fillets marinated for 20 h (82.90 and 82.26, respectively). The lightness of all examined samples of fillets was dependent upon the sample type (Table 3). Redness and yellowness were not affected by sample type, marination time and interaction effect of these two factors.

Tenderness has been identified as the most important factor affecting consumer satisfaction and perception of taste (Naveena et al., 2004). Warner-Bratzler shear force (WBSF) is an important indicator related to meat tenderness (Zhao et al., 2012; He et al., 2015). One of the ingredients of three-spice powder mixture used for samples marination was ginger powder. Ginger, beside antioxidant and antimicrobial, has strong proteolytic activity (Bhaskar et al., 2006; Naveena et al., 2004). Significantly $(P<0.05)$ lower WBSH values were observed in both fillets marinated during $20 \mathrm{~h}$ compared to unmarinated fillets and fillets marinated for $1.5 \mathrm{~h}$ (Table 3). Longer marination time may have increased meat tenderness by enhancing muscle fiber disruption (Naveena et al., 2004; Bhaskar et al., 2006; He et al., 2015). 
The results of juiciness show that the unmarinated fresh fillets had the highest value while the frozen-thawed fillets marinated for $20 \mathrm{~h}$ had the lowest value (41.86\% and $26.67 \%$, respectively) (Table 3 ). These results could be correlated with the results of cooking loss, thus, unmarinated fresh fillets had the lowest cooking loss, while the frozen-thawed fillets marinated for $20 \mathrm{~h}$ had the highest value of cooking loss (19.30\% and $44.73 \%$, respectively). Marination time did not have significant effect on cooked fillets juiciness, while sample type significantly affected the previously mentioned property.

Sensory property odor of examined fillet samples was in average evaluated as "very good", except frozen-thawed fillets marinated for $20 \mathrm{~h}$ which were ascribed a highest mark 7 („extreme good“) (Table 1). However, above mentioned sensory property was significantly influenced only by sample type. In general, other evaluated sensory properties of examined fillets were found to be significantly affected by the sample type. Taste of fresh fillets marinated for $20 \mathrm{~h}$ was marked significantly higher $(P<0.05)$ as compared to other examined fillets. Likewise, fresh fillets marinated for $20 \mathrm{~h}$ were evaluated significantly better $(P<0.05)$ than other samples with regard to sensory properties of juiciness and tenderness. Higher marks for juiciness and tenderness of previously mentioned fillets can be explained by higher marinade uptake. The higher sensory mark for tenderness for fresh fillets marinated for $20 \mathrm{~h}$ may have been in correlation with lower shear force value for these samples, than for other investigated samples. As well, aforementioned fillets had the highest (95.00\% of maximum quality) and frozen-thawed unmarinated fillets had the lowest mark for the overall sensory acceptability (83.39\% of maximum quality) (Figure 2). 
Table 3. Cooking loss, color parameters (CIE $L^{*} a^{*} b^{*}$ ), Warner-Bratzler shear force, juiciness and sensory properties of control and marinated breast fillets from fresh and frozen-thawed chicken breast meat.

\begin{tabular}{|c|c|c|c|c|c|c|c|c|c|}
\hline \multirow{4}{*}{ Property } & \multicolumn{6}{|c|}{ Fillet treatment } & \multirow{4}{*}{\multicolumn{2}{|c|}{$\begin{array}{l}\begin{array}{l}\text { Factor } \\
\text { significance }\end{array} \\
\text { Sample Time } \\
(\mathrm{S}) \quad(\mathrm{T})\end{array}$}} & \multirow{4}{*}{ SxT } \\
\hline & \multicolumn{3}{|c|}{ Fresh } & \multicolumn{3}{|c|}{ Frozen-thawed } & & & \\
\hline & \multicolumn{6}{|c|}{ Marination time (h) } & & & \\
\hline & 0 & 1,5 & 20 & 0 & 1,5 & 20 & & & \\
\hline $\begin{array}{l}\text { Cooking } \\
\text { loss }(\%)\end{array}$ & $19.30 \pm 4.64^{\mathrm{b}}$ & $21.49 \pm 2.67^{b}$ & $39.87 \pm 5.13^{\mathrm{a}}$ & $25.66 \pm 8.2^{\mathrm{b}}$ & $39.25 \pm 2.53^{\mathrm{a}}$ & $44.73 \pm 5.35^{\mathrm{a}}$ & $*$ & $*$ & $*$ \\
\hline \multirow{3}{*}{$\frac{\dot{0}}{0}$} & $83.62 \pm 1.77^{\mathrm{a}}$ & $83.70 \pm 1.16^{\mathrm{a}}$ & $82.90 \pm 1.31^{\mathrm{ab}}$ & $82.09 \pm 1.9^{\mathrm{b}}$ & $81.87 \pm 1.24^{b}$ & $\begin{array}{l}82.26 \pm 1.95^{\mathrm{a}} \\
\mathrm{b}\end{array}$ & $*$ & ns & ns \\
\hline & $3.26 \pm 0.88$ & $2.63 \pm 0.71$ & $3.60 \pm 1.35$ & $3.08 \pm 0.76$ & $2.72 \pm 0.53$ & $2.59 \pm 0.61$ & ns & ns & ns \\
\hline & $12.61 \pm 1.60$ & $12.18 \pm 0.75$ & $13.00 \pm 1.13$ & $13.53 \pm 1.49^{\mathrm{a}}$ & $12.65 \pm 1.30$ & $13.56 \pm 1.70$ & ns & ns & ns \\
\hline WBSF $(\mathrm{N})$ & $19.78 \pm 3.38^{\mathrm{a}}$ & $18.05 \pm 3.42^{\mathrm{a}}$ & $13.96 \pm 1.87^{\mathrm{b}}$ & $20.71 \pm 8.95^{\mathrm{a}}$ & $19.80 \pm 5.65^{\mathrm{a}}$ & $12.88 \pm 3.82^{b}$ & ns & $*$ & ns \\
\hline Juiciness $(\%)$ & $41.86 \pm 9.38^{\mathrm{a}}$ & $39.76 \pm 6.96^{\mathrm{ab}}$ & $38.09 \pm 5.08^{\mathrm{ab}}$ & $30.03 \pm 7.31^{\mathrm{c}}$ & $33.18 \pm 4.39^{\mathrm{bc}}$ & $26.67 \pm 3.87^{\mathrm{c}}$ & $*$ & ns & ns \\
\hline$\stackrel{\varrho}{\Xi}$ Odor & $6.00 \pm 0^{\mathrm{c}}$ & $6.30 \pm 0.27^{\mathrm{b}}$ & $6.00 \pm 0^{\mathrm{c}}$ & $6.00 \pm 0^{\mathrm{c}}$ & $6.00 \pm 0^{\mathrm{c}}$ & $7.00 \pm 0^{\mathrm{a}}$ & $*$ & ns & ns \\
\hline $\begin{array}{l}\text { : Taste } \\
\text { : }\end{array}$ & $5.95 \pm 0.28^{\mathrm{c}}$ & $6.30 \pm 0.27^{b}$ & $6.70 \pm 0.27^{\mathrm{a}}$ & $5.95 \pm 0.16^{\mathrm{c}}$ & $6.00 \pm 0^{\mathrm{c}}$ & $6.50 \pm 0^{\mathrm{ab}}$ & $*$ & $*$ & ns \\
\hline 긍 Juiciness & $6.15 \pm 0.63^{b}$ & $6.10 \pm 0.74^{b}$ & $6.90 \pm 0.22^{\mathrm{a}}$ & $5.45 \pm 0.37^{\mathrm{c}}$ & $6.00 \pm 0^{\mathrm{bc}}$ & $6.40 \pm 0.42^{\mathrm{ab}}$ & $*$ & $*$ & ns \\
\hline $\begin{array}{l}\text { D } \\
\text { Tenderne } \\
\text { ss }\end{array}$ & $6.50 \pm 0.33^{\mathrm{b}}$ & $6.30 \pm 0.67^{\mathrm{bc}}$ & $7.00 \pm 0^{\mathrm{a}}$ & $5.95 \pm 0.16^{\mathrm{c}}$ & $6.00 \pm 0^{\mathrm{c}}$ & $6.50 \pm 0.35^{\mathrm{b}}$ & $*$ & $*$ & ns \\
\hline
\end{tabular}

${ }^{\text {a-c }}$ Means within a row with different superscripts are significantly different $(P<0.05)$.

${ }^{\star} P<0.05, \mathrm{~ns}=$ not significant.

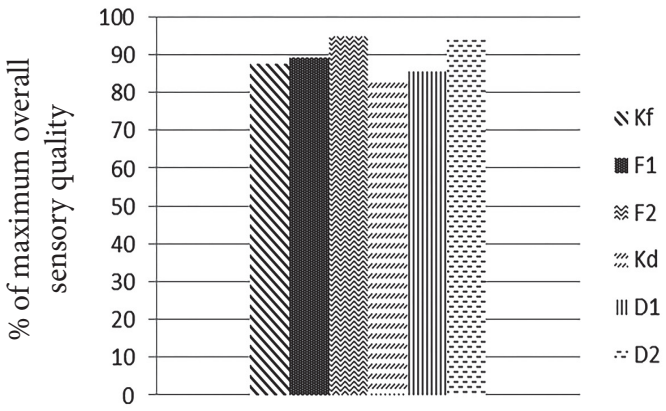

Samples

Figure 2. \% of maximal overall sensory quality 


\section{CONCLUSION}

This study evaluated the impact of sample type (fresh and frozen-thawed fillets) and marination time on cooking loss, color properties, Warner-Bratzler shear force, juiciness and sensory properties (odor, taste, juiciness and tenderness) of chicken breast meat. Marination time significantly affected cooking loss, WBSF values and most of the sensory properties (taste, juiciness and tenderness). However, sample type significantly affected cooking loss, lightness, juiciness and all investigated sensory properties.

\section{ACKNOWLEDGEMENT}

The research in this paper was financed by the Provincial Secretariat for Higher Education and Scientific Research, Autonomous Province of Vojvodina, Republic of Serbia No 142-451-3602/2017-01.

\section{REFERENCES}

1. Alvarado C., McKee S.: Marination to Improve Functional Properties and Safety of Poultry Meat. The Journal of Applied Poultry Research, 16, 113120, 2007.

2. Barbanti D., Pasquini M.: Influence of cooking conditions on cooking loss and ten-derness of raw and marinated chicken breast meat. $L W T, 38,8$, 895-901, 2005.

3. Bhaskar N, Sachindra N.M., Modi V.K., Sakhare P.Z., Mahendrakar N.S.: Preparation of proteolytic activity rich ginger powder and evaluation of its tenderizing effect on spent-hen muscles. Journal of Muscle Foods, 17, 174-184, 2006.

4. Bianchi M., Petracci M., Cavani C.: The use of marination to improve poultry meat quality. Italian Journal of Animal Science, 8, 2, 757-759, 2009.

5. Bjorkroth J.: Microbiological ecology of marinated meat products. Meat Science, 70, 3, 477-480, 2005.

6. Bowker B., Zhuang H.: Freezing-thawing and sub-sampling influence the marination performance of chicken breast meat. Poultry Science, 96, 34823488, 2017.

7. Fenton L.F., Hand L.W., Berry J.G.: Effects of marination holding time and temperature on chicken breast halves. Animal Science Research Report, 8994, 1993. 
8. Gujral H.S., Kaur A., Singh N., Sodhi S.N.: Effect of liquid whole egg, fat and textured soy protein on the textural and cooking properties of raw and baked patties from goat meat. Journal of Food Engineering, 53, 377-385, 2002.

9. He F.Y., Kim H.W., Hwang K.E., Song D.H., Kim Y.J., Ham Y.K., Kim S.Y., Yeo I.J., Jung T.J., Kim C.J.: Effect of Ginger Extract and Citric Acid on the Tenderness of Duck Breast Muscles. Korean Journal for Food Science of Animal Resources, 35, 6, 721-730, 2015.

10. Heath J.L., Owens S.L.: Reducing Variation in Marinade Retained by Broiler Breasts. Poultry Science, 70, 1, 160-166, 1991.

11. Kaale L.D., Eikevik T.M.: The development of ice crystals in food products during the superchilling process and following storage, a review. Trends in Food Science \& Technology, 39, 2, 91-103, 2014.

12. Leygonie C., Britza T.J., Hoffman L.C.: Impact of freezing and thawing on the quality of meat: Review. Meat Science, 91, 2, 93-98, 2012.

13. Mielnik M.B., Sem S., Egelandsdal B., Skrede G.: By-products from herbs essential oil production as ingredient in marinade for turkey thighs. LWT, 41, 93-100, 2008.

14. Naveena B.M., Mendiratta S.K., Anjaneyulu A.S.R.: Tenderization of buffalo meat using plant proteases from Cucumis trigonus Roxb (Kachri) and Zingiber officinale roscoe (Ginger rhizome). Meat Science, 68, 363-369, 2004.

15. Parks S.S., Reynolds A. E.,Wicker L.: Aqueous Apple Flavoring in Breast Muscle Has Physical, Chemical, and Sensory Properties Similar to Those of Phosphate-Marinated Controls. Poultry Science, 79, 1183-1188, 2000.

16. Smith D. P., Acton J. C.: Marination, cooking, and curing of poultry products. In: Poultry meat processing, Boca Raton, Florida: CRC Press, Taylor \& Francis Group, 2010.

17. Van Haute S., Raes K., Van der Meeren P., Sampers I.: The effect of cinnamon, oregano and thyme essential oils in marinade on the microbial shelf life of fish and meat products. Food Control, 68, 30-39, 2016.

18. Xiong Y.L., Kupski D.R.: Time-Dependent Marinade Absorption and Retention, Cooking Yield, and Palatability of Chicken Filets Marinated in Various Phosphate Solutions. Poultry Science, 78, 1053-1059, 1999.

19. Zhao G. Y., Zhou M. Y., Zhao H. L., Chen X. L., Xie B. B., Zhang X. Y., He H. L., Zhou B. C., Zhang Y. Z.: Tenderization effect of cold-adapted collagenolytic protease MCP-01 on beef meat at low temperature and its mechanism. Food Chemistry, 134, 4, 1738-1744, 2012. 
20. Zheng M., Detienne N.A., Barnes B.W., Wicker L.: Tenderness and yields of poultry breast are influenced by phosphate type and concentration of marinade. Journal of the Science of Food and Agriculture, 81, 82-87, 2000.

Primljeno: 11.11.2017. Odobreno: 25.12.2017. 